\title{
INFECTIOUS DISEASES
}

\section{NOTIFICATIONS}

ata in this Bulletin relate to Epiweeks 1 to 21. Table 4 lists the number of weekly reports made to the Epidemiology and Health Services Evaluation Branch this year, out of a possible 20 .

There has been an improvement in the quality of infectious diseases data received from Public Health Units (PHUs), both with respect to weekly reporting (Table 4) and to inclusion of basic epidemiological parameters on infectious disease notifications (Table 5). South West Region has complete reporting for all four reporting criteria reported in this Bulletin.

\begin{tabular}{|l|cl|}
\hline TABLE 4 & & \\
\hline $\begin{array}{l}\text { NUMBER OF WEEKLY REPORTS MADE } \\
\text { TO EPIDEMIOLOGY BRANCH - 1992 }\end{array}$ & & \\
\hline Public Health Unit & Number & Status \\
\hline Central/Southern Sydney & 16 & Complete \\
Eastern Sydney & 8 & Complete \\
South Western Sydney & 10 & Incomplete \\
Western Sector & 20 & Complete \\
Northern Sydney & 20 & Complete \\
Central Coast & 11 & Complete \\
Illawarra & 16 & Complete \\
Hunter & 15 & Complete \\
North Coast & 19 & Complete \\
New England & 18 & Complete \\
Orana and Far West & 20 & Complete \\
Central West & 14 & Complete \\
South West & 20 & Complete \\
South East & 20 & Complete \\
\hline
\end{tabular}

\section{TABLE 5}

PERCENTAGE OF NOTIFICATIONS WITH INCOMPLETE INFORMATION BY VARIABLE AND PUBLIC HEALTH UNIT, IANUARY-APRIL 1992

\begin{tabular}{|lccc|}
\hline Public Health Unit & Age & Sex & Aboriginality \\
\hline Central/Southern Sydney & 1.0 & Complete & 100.0 \\
Eastern Sydney & 5.5 & 5.3 & 97.8 \\
South Western Sydney & 2.7 & 3.5 & 22.4 \\
Western Sydney & 6.3 & 7.7 & 94.4 \\
Wentworth & 3.6 & 4.8 & 84.1 \\
Northern Sydney & 4.1 & 3.8 & 97.7 \\
Central Coast & 3.3 & 1.1 & 87.7 \\
Illawarra & 2.2 & 1.1 & 94.0 \\
Hunter & 2.7 & 1.3 & 99.1 \\
North Coast & 1.3 & 1.1 & 41.9 \\
New England & 27.1 & 9.8 & 68.3 \\
Orana and Far West & 6.9 & Complete & 33.9 \\
Central West & 4.5 & Complete & 69.2 \\
South West & Complete Complete & Complete \\
South East & 1.5 & 3.1 & Complete \\
\hline
\end{tabular}

\section{SEXUALLY TRANSMITTED DISEASES — NOTIFIABLE}

Gonorrhea is a laboratory-notifiable condition. One hundred and thirty-six notifications were received to the end of May, compared with 177 for the same period in 1991
- a 13 per cent decrease. Taking into account reporting delays, the total for 1992 is compatible with the decline of gonorrhea incidence observed since 1982.

Syphilis is doctor-notifiable. To the end of May 172 notifications of syphilis had been received. This compares with the 245 observed for the same period in 1991 - a 30 per cent decrease, which suggests a level of underreporting. Sexual Health Clinics (SHCs) had been reluctant to notify syphilis cases under the original provisions of the Public Health Act as they were required to include identifying data. A change to the Regulation in April allows SHCs to notify cases using the first two letters of the given and family names, if all public health action has been carried out.

Statistics on the cases of AIDS are now being entered on the Infectious Diseases Surveillance System (IDSS) by Public Health Units. By the end of May 53 cases had been entered into IDSS. Most were from the Northern Sydney and Central and Southern PHUs.

SEXUALLY TRANSMISSABLE DISEASES - NON NOTIFIABLE Several sexually transmissable diseases that were notifiable under the Public Health Act 1902 need no longer be routinely reported to the Health Department following the passing of the Public Health Act 1991. Surveillance of Chlamydia trachomatis, Donovanosis, genital herpes and genital warts, non-specific urethritis and Lymphoma granuloma will now occur through Sexual Health Centres reporting to PHUs. (See Table 6.)

\section{MeAsLes}

Ten Area Health Services and Regions notified a total of 25 cases of measles during May.

Twenty-one notifications ( 84 per cent) were for children over the age of 12 months, and were therefore "preventable" through age-appropriate immunisation. Measles immunisation is recommended as a combined measlesmumps-rubella vaccine at the age of 12 months.

The Hunter Area notified 13 cases for a rate of 32.8 notifications per 100,000 population per year.

\section{HePATITIS C}

This condition is being notified more often. Caution is required in interpreting notification data. Available tests do not distinguish between incident and prevalent cases. During May, only three of 103 notifications for hepatitis C were described as acute episodes.

In addition, test sensitivity has increased in the past two years. Blood donations in NSW have been screened for hepatitis C since February, 1990. During May the NSW Health Department became aware of eight cases of blood and blood products contaminated with hepatitis $\mathrm{C}$ that had been transfused during 1991.

Intravenous drug use remains the highest risk factor for acquisition of hepatitis $\mathrm{C}$.

\section{TABLE 6}

NOTIFICATIONS OF NON-NOTIFIABIE SEXUALIY TRANSMITTED DISEASES RECEIVED IN MAY 1992 BY AREA HEALTH SERVICE/REGION.

' Cumulative statistics to April 1992 2 Cumulative statistics to March 19

S
4 Males, females to March, and femal les to April 1992 istatistics for part of May

* New cases.

$\begin{array}{lllllllllllll}\text { AHS } & \text { CSA } & \text { SSA } & \text { ESA }^{1} & \text { SWS WSA +WEN } & \text { NSA }^{3} & \text { CCA } & \text { ILL HUN } & \text { NCR NER } & \text { OFR } & \text { CWR SWR } & \text { SER }\end{array}$
Disease

Chlamydia trachomatis

Donovanosis

Genital herpes

Genital warts

Non-specific urethritis

Lymphoma granuloma

\section{ILL HUN4 NCR NER \\ OFR CWR SWR ${ }^{6}$ SER}

$\begin{array}{rrr}92 & 19 & 2 \\ - & - & - \\ 198 & 13 & 2 \\ 456 & 94 & 24 \\ 287 & 107 & 8\end{array}$

$\begin{array}{cc}2 & 1 \\ - & - \\ 2 & 17^{*} \\ 8 & 30^{*} \\ & 19\end{array}$

$-$

\begin{tabular}{|ccc|}
\hline 1 & 1 & - \\
- & - & - \\
$7^{*}$ & 1 & 4 \\
\hline $0^{*}$ & 6 & - \\
- & - & - \\
\hline
\end{tabular}




\section{Q FEVER VACCINATION PROGRAM IN NEW ENGLAND REGION}

Q fever is a well recognised health hazard for abattoir workers, dairy workers, shearers, wool sorters, tanners and veterinarians. It is contracted by the inhalation of aerosols or dust contaminated by the infected products of conception of cattle, sheep and goats. The infectious agent is a rickettsia, Coxiella burnettii.

The New England Region was one of four Health Regions in NSW with high notifications of Q fever (18 per 100,000 population in 1990). The perceived costs in employee claims under the Occupational Health \& Safety Act were identified as high by the abattoir administration.

The five abattoirs in the Region were approached in July 1991 with a proposal to screen and vaccinate their workforce against $Q$ fever. Discussions were held with abattoir managers, personnel managers, occupational health nurses and union representatives. Background information was gained from the Central West Region, where a testing program had been implemented, and from Professor Barry Marmion of Adelaide.

Screening involves taking a short medical and occupational history, a skin-test and venipuncture for $\mathrm{Q}$ fever serology. The skin-test is read five to seven days later, when pathology results are also received. Vaccination is offered only to those who have negative serology and skin tests.

The New England program

The Public Health Nurse (PHN) was trained as a Q fever vaccinator by Professor Marmion. After accreditation the PHN trained the occupational health nurse at Gunnedah Abattoir, and initially assisted her with the screening of employees. This program began in September 1991 and continued until the expiry date of the only vaccine source in February 1992. With minimal disruption to the abattoir

\section{LEPROSY}

The first cases of leprosy in two years have been notified, from South West Region (1) and Central Sydney Area Health Service (2). Details of the three cases are as follows:

\begin{tabular}{|c|c|c|}
\hline AGE (YEARS) & SEX & COUNTRY OF BIRTH \\
\hline 34 & Male & Vietnam \\
51 & Female & New Guinea \\
77 & Male & India \\
\hline
\end{tabular}

Leprosy is primarily a disease of the tropics and subtropics. It is a disease of low infectivity, usually being transmitted after prolonged personal contact. Antibiotic treatment is effective. Infectiousness is lost within three days of treatment with rifampicin.

The diagnosis should be considered when a patient from a country where leprosy is endemic presents with unexplained neuropathy or skin lesions. As leprosy is adequately treated in the outpatient setting and laboratory diagnosis is not always reliable, had been retained on the list of conditions to be notified by all medical practitioners.

\section{HAEMOPHILUS INFLUENZAE INFECTIONS}

Ten notifications were received for Haemophilus influenzae infections during May. This compares with 22 notifications received for the same period in 1991.

A total of 59 notifications has been received for 1992. Twenty-three ( 39 per cent) were for children aged between 18 months and five years, and therefore potentially preventable by the currently available vaccine. operation, screening was offered for several hours a day, including for night-shift workers, up to four days a week.

Tamworth Abattoir, with 90 employees, has no occupational health nurse but was included in December 1991. The Public Health Nurse coordinated the program at this small abattoir one morning a week over four weeks.

Concurrently in Tamworth a group of 41 of the New England Dairymen's Association was screened and vaccinated. The cost of their vaccination was met by individuals or their employers.

The combined abattoir program tested 655 employees (110 females, 545 males). Serology and skin testing demonstrated that 340 ( 52 per cent) had previously been infected. Of these:
- 315 (48 per cent) had negative serology and skin test;
- $\quad 111$ (17 per cent) had both positive serology and skin test;
- $\quad 183$ (28 per cent) had positive serology only; and 46 ( 7 per cent) had positive skin test only.

Vaccination was offered to the 315 serology and skin-test negative reactors.

In comparison, of the 41 dairymen screened eight (20 per cent) had been previously infected. Four (10 per cent) had positive serology only and four (10 per cent) had a positive skin test and negative serology.

Vaccine availability has limited the program to the present participants and prevented its extension to the remaining abattoirs.

Contributed by Greg Bell, Senior Environmental Health Officer, Cathy Johnson, Public Health Nurse and John Rooney, Director, Public Health Unit.

\section{Q FEVER}

As the vaccine against $Q$ fever is unavailable, the serological screening and immunisation program has been stopped. The success of the program has been reflected in the 52 per cent decrease in Q fever notifications in 1992 compared with the same period in 1991.

\section{FOODBORNE ILLNESSES}

Notifications for foodborne diseases have decreased for several reasons. Among these is:
- The new notification criteria for foodborne diseases notified as single cases, unless they occur in an "institution"); and
- Delays in data entry of foodborne notifications as the Food Branch processes notifications and embarks on surveillance and public health action before passing notifications to PHUs.

This second factor will be streamlined with the integration of Food Branch officers into the PHUs.

\section{INFLUENZA}

Six PHUs (Western Sydney, Central/Southern Sydney, Illawarra, Central Coast, Central West Region and South Eastern Region) provide General Practitioner Sentinel Surveillance data on influenza. The rate of influenza, expressed as the number of cases per 100 consultations, increased from 1.63 at the beginning of May to 7.37 by the first week of June.

The national reporting scheme ASPREN recorded an increase in "influenza-like illness" in late April and early May. 


\section{TABLE 7}

INFECTIOUS DISEASE NOTIFICATIONS

BY HEALTH AREA AND REGION

CUMULATIVE 1992

\begin{tabular}{|c|c|c|c|c|c|c|c|c|c|c|c|c|c|c|c|c|c|c|c|}
\hline CONDITION & CSA & SSA & ESA & sws & WSA & WEN & NSA & CCA & ILL & HUN & NCR & NER & OFR & CWR & SWR & SER & OTH & U/K & TOTAL \\
\hline Adverse event after immunisation & 1 & 1 & - & - & - & - & - & 1 & - & 1 & 3 & 5 & .- & - & - & 2 & - & - & 14 \\
\hline AIDS infection & 9 & 2 & - & 2 & 5 & 5 & 12 & 1 & 1 & 2 & 6 & 2 & $\overline{-}$ & 1 & 4 & 1 & - & - & 53 \\
\hline Arboviral infection & - & - & - & - & 1 & 3 & 4 & 4 & 1 & 19 & 92 & 21 & 24 & - & 17 & - & - & - & 186 \\
\hline Diphtheria & - & - & $\bar{s}$ & - & - & - & - & - & - & - & 1 & - & - & - & - & - & - & - & 1 \\
\hline Foodborne illness (NOS) & - & - & 24 & 1 & 16 & 6 & - & 10 & - & 6 & - & 2 & 17 & 1 & 1 & - & - & - & 84 \\
\hline Gastroenteritis (instit) & 1 & $\overline{-}$ & 1 & - & 3 & 2 & $\bar{z}$ & - & $\bar{a}$ & 34 & 1 & 92 & 2 & $\bar{z}$ & - & $\overline{-}$ & - & - & 136 \\
\hline Gonorrhoea infection & 15 & 3 & 59 & 6 & 8 & - & 7 & - & 2 & 3 & 8 & 5 & 6 & 7 & 2 & 5 & - & - & 136 \\
\hline H. influenzae epiglottitis & - & - & - & - & 2 & 1 & - & - & $=$ & 4 & 2 & 2 & - & - & 1 & - & - & - & 12 \\
\hline $\mathrm{H}$. influenzae meningitis & 1 & $=$ & - & - & 2 & 3 & 9 & - & 3 & 3 & 3 & - & 1 & - & 2 & 2 & - & - & 29 \\
\hline H. influenzae septicaemia & - & - & 1 & 2 & 2 & - & 2 & - & - & 1 & 1 & - & - & - & 1 & $=$ & - & - & 10 \\
\hline $\mathrm{H}$. influenzae infection (NOS) & - & - & 1 & $=$ & 2 & - & - & 1 & - & - & - & 1 & 1 & - & $=$ & 2 & - & - & 8 \\
\hline Hepatitis A - acute viral & 16 & 8 & 73 & 12 & 25 & 4 & 63 & $i$ & 14 & 22 & 40 & 78 & 23 & 3 & 5 & 3 & - & - & 390 \\
\hline Hepatitis A - unspecified & - & - & & & - & & 3 & - & $\overline{-}$ & - & $\bar{z}$ & & - & - & - & - & - & - & 3 \\
\hline Hepatitis B - acute viral & - & 1 & 3 & 4 & 4 & 2 & 3 & - & 5 & 1 & 7 & 2 & 14 & - & - & - & - & - & 46 \\
\hline Hepatitis B - unspecified & 123 & 96 & 31 & 111 & 151 & 18 & 115 & 11 & 6 & 55 & 21 & 18 & 6 & 4 & 8 & 12 & 2 & - & 788 \\
\hline Hepatitis C-acute viral & & 1 & 1 & 14 & 6 & - & 3 & & 2 & & 9 & 4 & 4 & 1 & - & 1 & $=$ & - & 46 \\
\hline Hepatitis C- unspecified & 148 & 35 & 116 & 27 & 87 & 15 & 87 & 34 & 22 & 201 & 208 & 21 & 2 & 4 & 6 & 8 & - & - & 1021 \\
\hline Hepatitis D - unspecified & - & - & 1 & - & - & - & - & - & - & 1 & - & - & - & - & - & - & - & - & 2 \\
\hline Hepatitis, acute viral (NOS) & - & $=$ & - & 4 & - & - & $=$ & 1 & - & - & - & 1 & 2 & 1 & 1 & $\overline{-}$ & - & $\overline{-}$ & 10 \\
\hline HIV infection ${ }^{*}$ & 37 & 14 & 93 & 4 & 10 & 4 & 15 & 2 & 2 & 8 & 10 & - & 2 & - & 1 & 3 & - & 102 & 307 \\
\hline Hydatid disease & - & - & & & & $=$ & & & & & 1 & 2 & $=$ & 1 & - & $=$ & - & - & 4 \\
\hline Legionnaires' disease & - & 1 & 1 & 28 & 7 & 1 & 4 & 2 & 1 & 1 & 1 & - & - & - & - & 1 & - & - & 48 \\
\hline Leprosy & 2 & - & - & - & - & - & - & - & - & - & - & - & - & - & 1 & - & - & - & 3 \\
\hline Leptospirosis & - & 1 & - & - & - & - & $=$ & - & - & - & 1 & 2 & - & 3 & - & - & - & - & 7 \\
\hline $\begin{array}{l}\text { Listeriosis } \\
\text { L }\end{array}$ & - & 1 & - & - & - & 1 & 2 & - & - & - & 1 & $=$ & - & 1 & $\overline{-}$ & - & - & - & 6 \\
\hline Malaria & - & 1 & - & 1 & 2 & - & 7 & - & 2 & 2 & 1 & 2 & 1 & 1 & 2 & 2 & - & - & 24 \\
\hline Measles & 6 & 3 & 4 & 11 & 18 & 3 & 15 & 6 & 9 & 33 & 13 & 9 & 7 & 5 & - & 7 & - & - & 149 \\
\hline Meningococcal meningitis & 1 & 2 & - & 1 & 1 & 1 & - & 1 & 1 & 3 & 1 & $=$ & 1 & - & - & - & - & - & 13 \\
\hline Meningococcal septicaemia & - & - & - & 1 & - & - & - & - & - & - & - & - & - & - & - & - & - & - & 1 \\
\hline Meningococcal infection (NOS) & - & - & - & - & - & - & 1 & - & 1 & - & - & 2 & - & - & - & - & - & - & 4 \\
\hline Mumps & - & - & - & 1 & 3 & - & 1 & - & - & 3 & 1 & - & - & - & 1 & 1 & - & - & 11 \\
\hline Mycobacterial atypical & 8 & 3 & 19 & - & 9 & 1 & 9 & - & 1 & 10 & - & - & - & - & - & $=$ & - & - & 60 \\
\hline Mycobacterial tuberculosis & 14 & 10 & 13 & 10 & 14 & 3 & 28 & 3 & 3 & 1 & 3 & 6 & - & - & - & 2 & - & - & 110 \\
\hline Mycobacterial infection (NOS) & - & - & - & - & 4 & 1 & 2 & 1 & 4 & 3 & $=$ & 1 & 1 & - & 1 & - & - & - & 18 \\
\hline Pertussis & - & 5 & 1 & 6 & 3 & - & $\overline{9}$ & - & - & 2 & 23 & - & - & - & $\overline{-}$ & - & - & - & 49 \\
\hline Q fever & - & - & - & - & 1 & 1 & - & 1 & - & 4 & 17 & 9 & 13 & - & 2 & - & - & - & 48 \\
\hline Rubella & 1 & - & 2 & - & 4 & 1 & 8 & - & - & 1 & 3 & - & - & $=$ & $=$ & 2 & - & - & 22 \\
\hline Salmonella (NOS) & 9 & 11 & 23 & 17 & 22 & 10 & 44 & 11 & 6 & 17 & 32 & 18 & 13 & 9 & 6 & 13 & - & - & 261 \\
\hline Salmonella bovis morbificans & 1 & 2 & - & - & 2 & - & & . & . & r & 1 & & & & & - & - & - & 4 \\
\hline Salmonella typhimurium & 3 & 11 & 2 & 1 & 3 & - & 12 & 3 & 3 & 12 & 2 & 1 & 2 & - & 2 & - & - & - & 57 \\
\hline Syphilis infection & 25 & 10 & 19 & 9 & 8 & 1 & 17 & - & 2 & 4 & 26 & 11 & 34 & 3 & 1 & 1 & 1 & - & 172 \\
\hline Tetanus & & & & 1 & & - & & - & 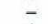 & - & - & - & - & - & & - & - & - & 1 \\
\hline Typhoid and paratyphoid & 1 & - & 1 & - & 2 & - & 3 & - & 1 & - & - & - & - & - & 2 & - & - & - & 10 \\
\hline
\end{tabular}

* Data to April only.

\section{TABLE 8}

INFECTIOUS DISEASE NOTIFICATIONS

BY HEALTH AREA AND REGION

May 1992

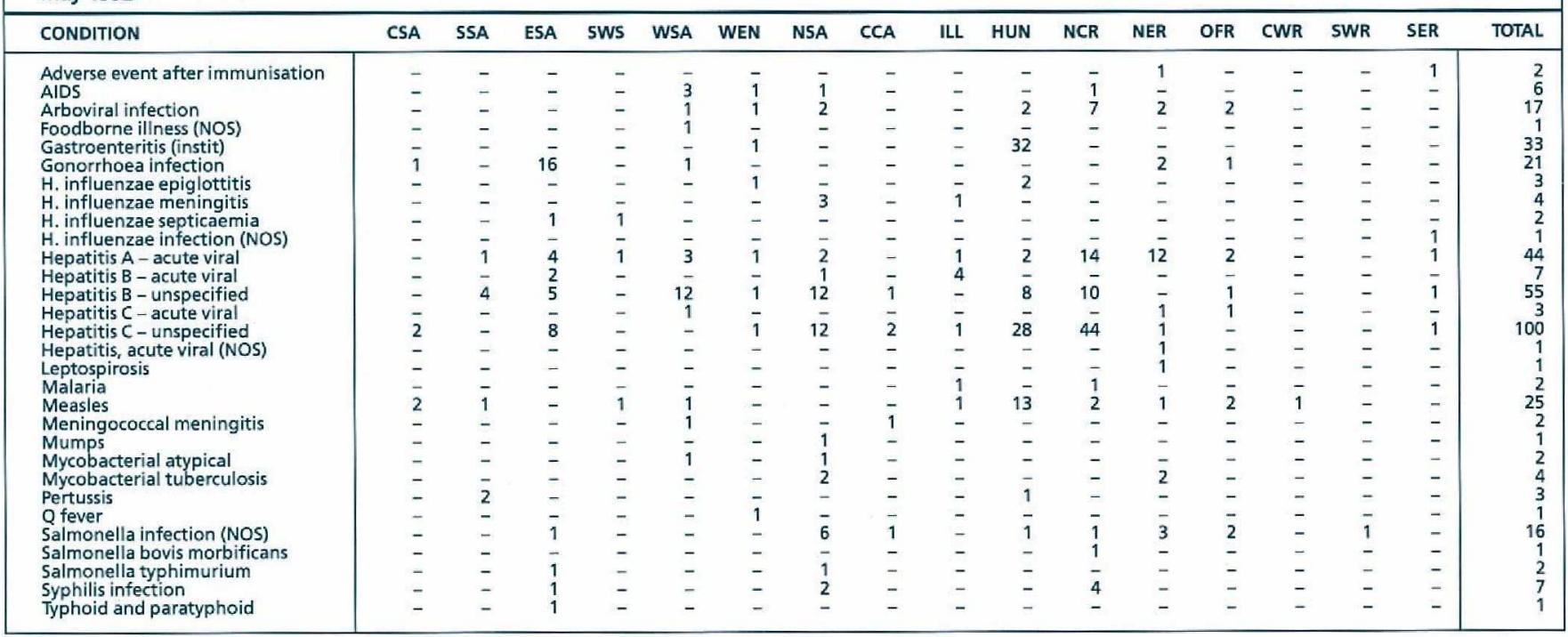

Abbreviations used in this Bulletin:

CSA Central Sydney Health Area, SSA Southern Sydney Health Area, ESA Eastern Sydney Health Area, SWS South Western Sydney Health Area, WSA Western Sydney CSA Central Sydney Health Area, SSA Southern S H N Health Area, WEN Wentworth Health Area, NSA Northern Sydney Health Area, CCA Central Coast Health Area, ILL IIIawarra Health Area, HUN Hunter Health Area, NCR North Coast Health Region, NER New England Health Region, OFR Orana \& Far West Health Region, CWR Central West Health Region, SWR South West Health Region, North Coast Health Region, NER New England Health Region, OFR Orana \& Far West Health Region,
SER South East Health Region, OTH Interstate/Overseas, U/K Unknown, NOS Not Otherwise Stated

Please note that the data contained in this Bulletin are provisional and subject to change because of late reports or changes in case classification. Data are tabulated where possible by area of residence and by the disease onset date and not simply the date of notification or receipt of such notification. 


\section{NEWS AND COMMENT}

\section{NEW STATISTICS TO PLUG THE GAPS}

\section{TABLE 9}

SUMMARY OF NSW INFECTIOUS DISEASE NOTIFICATIONS MAY 1992

\begin{tabular}{|c|c|c|c|c|}
\hline \multirow[b]{3}{*}{ CONDITION } & \multicolumn{4}{|c|}{ Number of Cases Notified } \\
\hline & \multicolumn{2}{|c|}{ Period } & \multicolumn{2}{|c|}{ Cumulative } \\
\hline & $\begin{array}{l}\text { May } \\
1991\end{array}$ & $\begin{array}{l}\text { May } \\
1992\end{array}$ & $\begin{array}{c}\text { May } \\
1991\end{array}$ & $\begin{array}{c}\text { May } \\
1992\end{array}$ \\
\hline Adverse reaction & N/A & 2 & N/A & 14 \\
\hline AIDS & 30 & 6 & 169 & 53 \\
\hline Arboviral infection & 37 & 17 & 354 & 186 \\
\hline Brucellosis & 1 & - & 2 & - \\
\hline Cholera & - & - & - & - \\
\hline Diphtheria & - & - & - & 1 \\
\hline Foodborne illness (NOS) & 257 & 1 & 1481 & 84 \\
\hline Gastroenteritis (instit.) & 3 & 33 & 27 & 136 \\
\hline Gonorrhoea & 27 & 21 & 177 & 136 \\
\hline H. influenzae epiglottitis & 1 & 3 & 3 & 12 \\
\hline $\mathrm{H}$. influenzae $\mathrm{B}$ - meningitis & 5 & 4 & 12 & 29 \\
\hline H. influenzae B - septicaemia & 1 & 2 & 2 & 10 \\
\hline H. influenzae infection (NOS) & 18 & 1 & 50 & 8 \\
\hline Hepatitis A & 65 & 44 & 199 & 393 \\
\hline Hepatitis B & 106 & 62 & 466 & 834 \\
\hline Hepatitis C & 17 & 103 & 104 & 1067 \\
\hline Hepatitis D & N/A & - & N/A & 2 \\
\hline Hepatitis, acute viral (NOS) & 52 & 1 & 187 & 10 \\
\hline HIV infection* & 70 & 65 & 320 & 307 \\
\hline Hydatid disease & - & - & 1 & 4 \\
\hline Legionnaires' disease & 2 & - & 17 & 48 \\
\hline Leprosy & - & - & - & 3 \\
\hline Leptospirosis & 2 & 1 & 22 & 7 \\
\hline Listeriosis & - & - & 3 & 6 \\
\hline Malaria & 24 & 2 & 85 & 24 \\
\hline Measles & 15 & 25 & 178 & 149 \\
\hline Meningococcal meningitis & 3 & 2 & 11 & 13 \\
\hline Meningococcal septicaemia & 1 & - & 7 & 1 \\
\hline Meningococcal infection & & - & & \\
\hline $\begin{array}{l}\text { (NOS) } \\
\text { Mumps }\end{array}$ & $\begin{array}{r}6 \\
-1 / 4\end{array}$ & $\overline{1}$ & $\begin{array}{r}14 \\
\text { N/A }\end{array}$ & $\begin{array}{r}4 \\
11\end{array}$ \\
\hline Mycobacterial tuberculosis & 21 & 4 & 99 & 110 \\
\hline Mycobacterial - atypical & 11 & 2 & 39 & 60 \\
\hline Mycobacterial infection & & & & \\
\hline (NOS) & 20 & - & 79 & 18 \\
\hline Pertussis & 3 & 3 & 24 & 49 \\
\hline Plague & - & - & - & - \\
\hline Poliomyelitis & - & - & - & - \\
\hline Q fever & 20 & 1 & 101 & 48 \\
\hline Rubella & 7 & - & 11 & 22 \\
\hline Salmonella infection (NOS) & 127 & 19 & 692 & 322 \\
\hline Syphilis & 65 & 7 & 245 & 172 \\
\hline Tetanus & 1 & - & 2 & 1 \\
\hline Typhoid and paratyphoid & 1 & 1 & 33 & 10 \\
\hline Typhus & - & - & - & - \\
\hline Viral haemorrhagic fevers & - & - & - & - \\
\hline Yellow fever & - & - & - & - \\
\hline
\end{tabular}

*Data to April only.

\section{SURVEILLANCE OF ANTIBIOTIC SENSITIVITY OF GONOCOCCI}

In the March quarter of 1992, 33 per cent of gonococcal isolates referred to the Australian Gonococcal Surveillance Program were fully sensitive to penicillin. Only 17 per cent were found to be penicillinase producers (PPNG).

The proportion of strains fully sensitive to the penicillin group of antibiotics continues to rise. Despite this increase, more than a quarter of all strains examined were resistant to penicillin, either through lactamase production or intrinsic resistance. Twenty of $25 \mathrm{PPNG}$ isolated in this quarter were imported from overseas and only three local infections with PPNG were recorded. This confirms the previously reported decline in the endemic transmission of PPNG in Sydney.

Contributed by Dr John Tapsall, Prince of Wales Hospital. n Australia, private hospitals provide a significant

proportion of health services and employ a large proportion of the health workforce. But there are only very limited data available on their resources, finances and activities.

A new nation-wide Private Health Establishments Collection being conducted by the Australian Bureau of Statistics (ABS) this month will provide a variety of statistics about private hospitals and day surgeries. This will fill some of the most serious gaps in Australia's health information systems.

The collection is to be done annually following the recognition by the Australian Health Ministers' Advisory Council (AHMAC) and by agencies responsible for the planning and administration of health care in Australia of the need for national statistics and the important role played by the private sector in provision of institutional health services.

The information being collected is based on the National Minimum Data Set endorsed by AHMAC and also includes other details needed by the private hospital sector. It will provide feedback to assist in management and policy development and allow individual hospitals to see how their business is performing in relation to trends in the industry. This, with information also about public hospitals collected by the Australian Institute of Health, will provide the first comprehensive set of national statistics relating to hospitals which is comparable across all States and Territories.

The first collection will be for the 1991-92 financial year. The questionnaires will collect information about facilities and activities, types of inpatients and non-inpatients treated, staffing, finances, fees and charges.

Content of the questionnaires was designed in close consultation with the Australian Institute of Health, Department of Health, Housing and Community Services and health industry associations. The ABS has also consulted a number of hospitals to test the content and design of the questionnaires.

The ABS is required by the Census and Statistics Act to maintain the secrecy of all information provided to it. No identifiable information about individual hospitals or chains of hospitals will be released. The data are for release in aggregate form only.

Results from the collection are to be released in April 1993. The ABS is keen to hear from people interested in using the statistics so their views can be used to help shape the content and formats of the output. If you want to help in this way, or wish to find out more about the survey, contact Keith Carter or Brian Holliday on 008806415 (toll free).

\section{FIRST PUBLIC HEALTH NETWORK CONFERENCE}

A conference for presentation of scientifically excellent projects undertaken by members of the Public Health Network is planned for November this year in Sydney. It is intended that the conference, organised by the Epidemiology Branch and Public Health Officers, will become an annual event. Suitable topics for presentation will include investigation of a disease cluster, assessment of an environmental health hazard, or implementation or evaluation of a public health program. Further details will be provided in the next Public Health Bulletin. 